\title{
Friend or Foe? The Role of State and Mutual Fund Ownership in the Split Share Structure Reform in China
}

\author{
Michael Firth, Chen Lin, and Hong Zou*
}

\begin{abstract}
The recent split share structure reform in China involves the nontradable shareholders proposing a compensation package to the tradable shareholders in exchange for the listing rights of their shares. We find that state ownership (the major owners of nontradable shares) has a positive effect on the final compensation ratio. In contrast, mutual fund ownership (the major institutional owner of tradable shares) has a negative effect on the compensation ratio and especially in state-owned firms. The evidence is consistent with our predictions that state shareholders have incentives to complete the reform quickly and exert political pressure on mutual funds to accept the terms without a fight.
\end{abstract}

\section{Introduction}

In this study, we examine the role played by government shareholders and mutual funds in the recent reform of the split share structure in China. In so doing we appeal to two recent strands of research: corporate privatization and restructuring in transitional economies and the incentives and conflicts of interests in financial intermediaries. ${ }^{1}$ Historically, the Chinese domestic A-shares are divided into tradable and nontradable shares, although both types of shares have the same

*Firth, mafirth@1n.edu.hk, Department of Finance and Insurance, Lingnan University, Tuen Mun, Hong Kong, China; Lin, chenlin@cityu.edu.hk, and Zou, hongzou@cityu.edu.hk, Department of Economics and Finance, City University of Hong Kong, 83 Tat Chee Ave., Kowloon Tong, Kowloon, Hong Kong, China. We thank Stephen Brown (the editor) and Zhiwu Chen (the referee) for insightful comments that have helped significantly improve the paper. We are also grateful to Mike Adams, Ping Lin, Wanbin Pan, Gang Wei, Jason Xiao, and Rongli Yuan for helpful suggestions on the paper. Firth acknowledges the financial support of an earmarked grant from the Hong Kong SAR (CERG LU340307) and Zou acknowledges the financial support of the Research Office of City University of Hong Kong (Grant No. 7200107). The excellent research assistance of Wanbin Pan is greatly appreciated.

${ }^{1}$ Wahal (1996), Hartzell and Starks (2003), Parrino, Sias, and Starks (2003), and Gaspar, Massa, and Matos (2005) represent some recent U.S. studies on the role of institutional investors in monitoring the agency incentives of managers. Chevalier and Ellison (1997), Mahoney (2004), Davis and Kim (2007), and Mehran and Stulz (2007) discuss conflicts of interest in the U.S. setting. Examples of studies on privatization in transitional economies include Chen, Firth, and Rui (2006) and Gupta (2005). 
cash flow and voting rights. This unique split share structure can lead to divergent interests and incentive conflicts between tradable and nontradable shareholders and has long been recognized as the source of many corporate governance problems in China (see Chen, Firth, Gao, and Rui (2006), Chen, Firth, Xin, and Xu (2008), and Feinerman (2007)). To help solve the fundamental governance problems, the Chinese government initiated a split share structure reform program in April 2005. The aim of the reform is to convert nontradable shares into tradable shares.

The nontradable shareholders gain from the reform as their shares become tradable (this increases liquidity and enables controlling shareholders to sell at market prices $^{2}$ ). In contrast, tradable shareholders may suffer in the short term because there is an extra supply of tradable shares in the market and this could lead to a steep decline in stock prices. ${ }^{3}$ To implement the reform, the nontradable shareholders have to negotiate with the tradable shareholders on a suitable compensation plan for converting nontradable shares to tradable shares; the government does not set the compensation terms. The plan needs approval by at least two-thirds of the voting tradable shares. In most cases, the compensation involves the nontradable shareholders giving shares to the tradable shareholders.

The roles of the state shareholders and mutual funds in this reform are particularly interesting. The state is the largest nontradable shareholder, while mutual funds are the largest type of institutional investor in tradable shares in China's stock market. The nontradable shareholders need to offer compensation to tradable shareholders (including mutual funds) in order for the latter to agree to the reform. In theory, the interests of mutual funds should align with the interests of the individual investors in tradable shares. Individual investors can therefore free ride on the efforts of mutual funds in the belief that the funds will look after their interests (Davis and Kim (2007)). ${ }^{4}$ However, as recent research (Mehran and Stulz (2007)) attests, the incentives facing financial institutions are complex, and conflicts of interest and political pressures often arise. We will show how political pressure, in particular, extends to the very specific case of mutual fund voting on the share structure reform proposals of listed firms in China. The share structure reform program provides a natural experimental setting within which to examine the role of mutual funds in corporate governance and investor protection.

We find that there is a positive and statistically significant relation between state ownership and the final compensation ratio. In addition, there is strong evidence that the positive effect of state ownership on compensation decreases with the level of mutual fund ownership. This represents prima facie evidence that mutual funds do not always act in the best interests of their unit holders. The results are consistent with our argument that the government has strong

\footnotetext{
${ }^{2}$ A significant price discount usually exists for illiquid securities such as nontradable shares (see Kahl, Liu, and Longstaff (2003), Longstaff (1995), (2001)).

${ }^{3}$ However, this loss is reduced if the reform process leads to an overall improvement in the firm's performance due to improved governance and management incentives.

${ }^{4}$ Furthermore, there is evidence from China that mutual fund ownership helps boost a firm's performance (Yuan, Xiao, and Zou (2008)) and that this benefits all shareholders.
} 
incentives to complete the reform smoothly and quickly through two mechanisms. First, the state-controlled entities offer a relatively high compensation ratio (visà-vis private-controlled listed firms) to tradable shareholders so that agreement is reached quickly. Second, the state exerts political pressure on the mutual fund management company to refrain from bargaining for better terms so the negotiations go smoothly and speedily. The negative impact of the interaction between mutual fund ownership and state ownership on the compensation ratio supports the view that mutual funds bow to political pressure to help state-owned firms get the reform done quickly and at a relatively lower cost. We also conduct an event study that examines the market reaction to the announcement of the final compensation ratio and find that the presence of mutual funds weakens the positive link between the announced compensation ratio and abnormal returns. Therefore, the abnormal stock returns for state-owned firms with mutual fund ownership is significantly lower than for firms without mutual fund ownership after controlling for the effect of the compensation ratio. This implies that individual investors are disappointed at the role of mutual funds in the reform bargaining process in state-owned firms. Overall, these findings lend support to our argument that political pressure compromises the role of mutual funds in maximizing the returns to their unit holders. Our results illustrate how the government steered the share structure reform by influencing both parties to the negotiation (the nontradable shareholders and the tradable shareholders). The results imply that individual investors cannot rely on mutual funds to take actions that are always in the best interests of all the tradable shareholders.

We organize the remainder of the paper as follows. In Section II we briefly introduce the reform of the split share structure in China. We discuss the link between state and mutual fund ownership and the compensation ratio offered by nontradable shareholders in Section III. In so doing we provide an in-depth analysis of the incentives of the government and mutual fund companies. Section IV describes the sample and variables, and Section V reports and discusses the empirical results. Section VI concludes.

\section{The Split Share Structure Reform}

\section{A. Split Share Structure and Firm Ownership}

China established the Shanghai and Shenzhen stock exchanges in the early 1990s in order to help revitalize and refinance its ailing state-owned enterprises (SOEs) and to help instill some elements of market discipline on top management. At the same time, however, the government wanted to maintain its control or influence over the SOEs and so it retained substantial ownership in many listed firms (Chen et al. (2008)). The controlling shareholder (whether state or private ${ }^{5}$ ) owns what are called state or legal person shares, and these are not publicly traded.

\footnotetext{
${ }^{5}$ Initially, listed firms had a state entity (central or local government or state ministry) as the major or controlling shareholder. Over time, however, private entities or individuals have become the controlling shareholder in many listed firms through mergers and acquisitions (Chow (2007)).
} 
In practical terms, government bureaucrats administer the state's shareholding. Shares issued to the public, on the other hand, are tradable and are divided into tradable A-shares (primarily for domestic investors) and foreign shares (B- and $\mathrm{H}$-shares).

Company ownership structure in China is highly concentrated by international standards, and the largest shareholder usually has effective control over the firm (Chen et al. (2008)). In contrast, each of the over 100 million individual investors in tradable shares typically owns a very small proportion of a company's total shares in issue. Not surprisingly, most individual investors in tradable shares tend to be free riders and short-term speculators who have few incentives to attend shareholders' meetings and exercise their shareholder rights (Tenev, Zhang, and Brefort (2002)).

\section{B. The Reform of the Split Share Structure}

Fully realizing the problems with the split share structure, the Chinese government began to reduce the proportion of state ownership by selling (nontradable) state-owned shares into the market in June 2001. However, the measure caused share prices to plummet by more than $30 \%$, as investors feared the increased supply of shares would flood the market (Kim, Ho, and St. Giles (2003)). In light of the strong adverse reaction from tradable A-shareholders, the government withdrew the plan in October 2002, and this marked the initial, albeit unsuccessful, attempt at share ownership reform. The chronic governance problems persisted, investors lost more confidence in the listed companies, and the stock market crashed. ${ }^{6}$

With the avowed intent to improve corporate governance, the government renewed its effort to reform the split share structure in 2005. This time, to make the reform palatable to the tradable shareholders, the government stated that the tradable shareholders have to be compensated and the compensation should be the result of mutual agreement between the two types of shareholders (tradable and nontradable). The reform involves the nontradable shareholders proposing a compensation package to the tradable shareholders. Negotiations then ensue between the major nontradable and tradable shareholders, and the initial proposal is revised into a formal plan that is voted upon by the respective shareholders. The plan needs approval from at least two-thirds of the total voting shares and twothirds of the voting tradable shares represented by investors who attend the shareholders' meeting, participate in the proxy voting, or cast their votes via the online voting system. ${ }^{7}$ If the proposal is not accepted then the nontradable shareholders have to come up with another proposal and negotiations begin afresh. The regulations state that there must be a gap of at least 3 months between proposals. Thus, the voting down of a proposal severely delays the reform and, in the case of

\footnotetext{
${ }^{6}$ During this period, the Shanghai Composite Index plunged from its peak of about 2,245 points to around 998 points at the end of May 2005, with market fundraising activities shrinking significantly.

${ }^{7}$ According to the regulations of the CSRC, B- and H-shareholders are not included in the reform, but their proportional stake in a company will stay the same after the reform.
} 
state-controlled firms, is seen as a black mark against the government bureaucrats who developed the proposal. ${ }^{8}$

In showing its determination to push forward the change, the China Securities Regulatory Commission (CSRC) set the end of 2006 as the target deadline for listed companies to complete the reform. The CSRC selected two batches of firms for a trial reform in May and June 2005. The trial was deemed a success, and the full-scale reform then started. Two official documents govern the operational procedures of the split share structure reform: Guidance Notes on the Split Share Structure Reform of Listed Companies ("Guidance Notes"), issued on August 23, 2005, and Administrative Measures on the Split Share Structure Reform of Listed Companies (the "CSRC Measures"), issued on September 4, 2005.

\section{The Roles of the State and Mutual Funds in the Share Structure Reform}

\section{A. The Role of State Ownership in the Share Structure Reform}

We hypothesize that other things being equal, the level of state ownership is likely to be positively related to the compensation ratio offered to tradable shareholders for the following three reasons: First, the government is eager to complete the reforms as early as possible, and it set the end of 2006 as the target date for finalizing agreements with the tradable shareholders. To set an example to other firms, the government wanted the state-controlled listed companies to complete the reforms quickly with a minimum of fuss and dissent from the tradable shareholders. To accomplish this, the bureaucrats who administer the state's shareholdings set more generous compensation terms than private-controlled firms. Given the debacle surrounding the earlier attempt to reform the share ownership structure, the government wanted to ensure success the second time around.

Second, the state wishes to list more wholly owned state enterprises, ${ }^{9}$ and the favorable investment sentiment that flows from a successful completion of the reform will help achieve this goal. By paying relatively high compensation in the share structure reform program, and thereby avoiding stockholder conflict, the state believes the reform is more likely to succeed and future listings of state enterprises will be easier.

Third, state-controlled firms are well-known for their acute owner-manager agency problems because of the vaguely defined state ownership rights and the delegation of management and monitoring functions to bureaucrats whose interests are not well aligned with those of the shareholders. The bureaucrats who administer the state's shareholdings are more interested in getting the reform completed quickly and efficiently, to gain political credit and maximize their movement up the political hierarchy. As such, the bureaucrats are less concerned about

\footnotetext{
${ }^{8}$ An illustration of the reform process is found in an earlier version of this paper (Firth, Lin, and Zou (2008)).

${ }^{9}$ For example, the Shanghai government recently unveiled a plan to have an additional 70 billion yuan of state-owned assets listed by the end of 2010 (see Chen (April 24, 2008)).
} 
the level of compensation ratio offered and the dilution of control associated with a higher compensation ratio, as it is not their personal investment. Moreover, the top managers in state-controlled listed firms also favor higher compensation (vis-à-vis the private-controlled firms) for exactly the same reasons as the state bureaucrats, to speed up the process and earn political kudos. ${ }^{10}$ In contrast, the private investors who own nontradable shares care more about the financial costs (that relate to the compensation ratio) instead of the political costs (that are associated with a prolonged reform period). As a result, private-controlled firms are likely to bargain very hard in order to minimize the dilution of their control and cash flow rights and so reduce the cost of the reform borne by them. Therefore, our first hypothesis is

H1. Other things being equal, the level of state ownership is positively related to the compensation ratio offered to the tradable shareholders.

\section{B. Mutual Funds in China and Their Role in the Share Structure Reform}

In order to help stabilize the stock markets and strengthen corporate governance, the government made a strategic decision in year 2000 to develop securities mutual funds as institutional investors in tradable shares (CSRC (2000)). Since then, the growth of the mutual fund industry has been phenomenal. The number of fund management companies increased from 6 in 1998 to 57 in 2006, while the number of mutual funds increased from 5 in 1998 to 323 in 2006. The net asset value of the mutual fund industry has increased from 10.74 billion yuan in 1998 to 818.48 billion yuan in 2006 . The mutual fund industry is dominated by several big players (e.g., Huaxia and Bosera), as evidenced by the market share of the top 5 and 10 fund management companies $(41 \%$ and $60 \%$ at the end of 2006 , respectively). The implication of this feature for the voting behavior of mutual funds is discussed later. ${ }^{11}$ Table 1 gives details of the rapid growth in mutual funds in China. The mean mutual funds' ownership in our sample firms represents about $14 \%$ of the total number of tradable A-shares in issue.

The voting rule set out by the CSRC Measures makes mutual funds a powerful and influential party in the reform bargaining process because mutual funds frequently appear among the top 10 shareholders of many listed companies. As an illustration, assume $30 \%$ of a firm's shares are tradable. According to the statistics of the Wind Financial Information System, the average voting rate ${ }^{12}$ of tradable A-shares in the reform vote is about $35 \%$. The proposal is rejected if just more than one-third of the votes are against it. In other words, the owners of $3.5 \%$ $(30 \% \times 35 \% \times 1 / 3)$ of the total number of shares in issue can effectively veto

\footnotetext{
${ }^{10}$ When the managers of state-controlled firms own shares in their company, they are tradable shares. This will motivate the managers to urge the nontradable shareholders to pay higher compensation.

${ }^{11}$ We thank Stephen Brown (the editor) for raising this issue.

${ }^{12}$ The voting rate is the proportion of shares that vote in the shareholders' meeting through proxy collection or via online ballot. Many individual investors do not bother to vote, particularly when mutual fund shareholders are present (we discuss this in Section V.C).
} 
TABLE 1

Mutual Fund Industry in China

Table 1 reports statistics on the mutual fund industry in China. Source: http://news1.jri.com.cn/news/2007-0105/000001897594.html (Web page of "China Financial Industry"). Market share information is compiled from the Wind Financial Information System

\begin{tabular}{|c|c|c|c|c|c|c|c|c|c|}
\hline \multirow[b]{2}{*}{ Mutual Fund Characteristic } & \multicolumn{9}{|c|}{ Evolution of China's Mutual Fund Industry } \\
\hline & 1998 & 1999 & 2000 & 2001 & 2002 & 2003 & 2004 & 2005 & 2006 \\
\hline \multicolumn{10}{|l|}{ Number of fund management companies } \\
\hline New & 6 & 4 & 0 & 5 & 6 & 12 & 12 & 8 & 4 \\
\hline Cumulative total & 6 & 10 & 10 & 15 & 21 & 33 & 45 & 53 & 57 \\
\hline \multicolumn{10}{|l|}{ Number of funds } \\
\hline Open-end funds & 0 & 0 & 0 & 3 & 18 & 60 & 112 & 177 & 269 \\
\hline Closed-end funds & 5 & 23 & 34 & 48 & 54 & 54 & 54 & 54 & 54 \\
\hline Total & 5 & 23 & 34 & 51 & 72 & 114 & 166 & 231 & 323 \\
\hline \multicolumn{10}{|l|}{ Net asset value (in billion yuan) } \\
\hline Open-end funds & 0.00 & 0.00 & 0.00 & 11.80 & 52.69 & 90.04 & 246.32 & 428.18 & 657.81 \\
\hline Closed-end funds & 10.74 & 51.42 & 84.56 & 70.00 & 71.71 & 86.20 & 80.96 & 82.21 & 160.67 \\
\hline Total & 10.74 & 51.42 & 84.56 & 81.80 & 124.40 & 176.24 & 327.28 & 510.39 & 818.48 \\
\hline \multicolumn{10}{|l|}{$\begin{array}{l}\text { Assets under the management } \\
\text { of the top } 5 \text { fund houses }\end{array}$} \\
\hline (in billion yuan) & 10.74 & 51.42 & 84.56 & 42.38 & 54.09 & 67.42 & 131.06 & 212.20 & 332.92 \\
\hline \multicolumn{10}{|l|}{$\begin{array}{l}\text { Assets under the management } \\
\text { of the top } 10 \text { fund houses }\end{array}$} \\
\hline (in billion yuan) & 10.74 & 51.42 & 84.56 & 69.49 & 91.69 & 109.71 & 196.00 & 298.15 & 490.31 \\
\hline \multirow{3}{*}{$\begin{array}{l}\% \text { of assets under the management } \\
\text { of the top } 5 \text { fund houses } \\
\% \text { of assets under the management } \\
\text { of the top } 10 \text { fund houses }\end{array}$} & & & & & & & & & \\
\hline & 100.00 & 100.00 & 100.00 & 51.80 & 43.48 & 38.25 & 40.04 & 41.58 & 40.68 \\
\hline & 100.00 & 100.00 & 100.00 & 84.95 & 73.71 & 62.25 & 59.89 & 58.42 & 59.90 \\
\hline
\end{tabular}

any reform plan should it prove to be unsatisfactory to these investors. The attitudes of the mutual fund shareholders are therefore crucial to the passage of the proposed reform plan. As such, it is interesting to examine the impact of mutual fund shareholders on the final compensation ratio to assess whether mutual funds have fought for better terms for the tradable shareholders. To gain a better understanding of the way mutual funds will vote on the share restructure proposals, we need to examine the way mutual funds are organized and governed, and the incentives and pressures they face.

In China, all mutual funds are contractual-form funds whereby investors enter into a contract with a fund management firm (the sponsor and trustee) and unit holders are the beneficial owners of the fund (Lu (Feb. 18, 2006)). In contrast to the situation in the U.S., ${ }^{13}$ a mutual fund in China does not have a board of directors to act as a fund governance body and a buffer between the unit holders and the fund management firm. One result of this is that it difficult to remove the fund management firm's mandate to manage the mutual fund. Additionally, compared with the corporate-form mutual funds that prevail in the U.S., contractual-form mutual funds provide fewer voting rights for fund investors (i.e., unit holders) and are therefore more prone to agency problems.

\footnotetext{
${ }^{13}$ Under the Investment Company Act of 1940 in the U.S., each open-end mutual fund is a company owned by mutual fund investors with a board of directors elected by the shareholders' meeting and comprising at least $40 \%$ of independent directors (Mahoney (2004)). In a review of the literature, Mehran and Stulz (2007) conclude that independent boards for mutual funds have value. Ferris and Yan (2007) and Khorana, Tufano, and Wedge (2007) provide further evidence on the advantages of having independent boards for mutual funds.
} 
These problems are particularly acute in China because of the weak and capricious legal system and high information asymmetry. ${ }^{14}$ China's Securities Investment Fund Law 2003 states that the fund unit holders enjoy voting rights on some important matters (e.g., on changing the fund manager), but in practice these rights are difficult to exercise because of stringent conditions that have to be met. ${ }^{15}$ Therefore, the governance of mutual funds in China effectively resides in the fund management firms whose interests may not perfectly align with those of the unit holders and in specific cases may significantly diverge (Huang (2006), Lu (Feb. 18, 2006)). Article 18 of the 2003 fund law prescribes that the fund management firm should represent the unit holders in exercising litigation rights and carrying out other legal actions for the interests of unit holders. However, in practice, fund management firms and fund managers never sought the opinion of the unit holders before they voted in the share structure reform (Huang (2006)).

Mutual funds reward the fund house and fund managers primarily based on the size of the fund they manage. If mutual fund shareholders fight hard for a better compensation ratio in the reform, fund performance will improve and the fund house will benefit via an increase in management fees resulting from the increased fund size. The increase in fund size comes from a better compensation ratio and from new unit sales that arise from an improved reputation for investment performance. This reward structure implies that managers may fight hard for higher compensation ratios if they have the voting rights. However, the CSRC took away the voting rights of the individual fund managers for the share structure reform decision and passed them to the investment decision committee of the fund management company. There are some not-so-subtle distinctions in the motivations of the individual fund managers and the investment decision committee of the fund management firm, which we discuss later in this section.

As discussed earlier, the CSRC is under pressure to ensure that the reform is completed in a timely manner. The longer the reform drags on, the higher the time-related costs (which include inhibiting the development of the stock market and the damage to the government's reputation and credibility). To speed up the process, the CSRC put direct pressure on mutual funds to vote in the interest of expediting the reform (Firth et al. (2008)). The CSRC holds regular meetings with all fund management firms and uses these occasions to stress the need for reaching a speedy and noncontentious conclusion to the share structure reform proposals.

The CSRC is able to wield considerable influence on the mutual fund industry for three main reasons. First, the CSRC is the regulatory body that oversees mutual funds, and their powers (vested by the Securities Investment Fund Law of 2003) are much greater than its U.S. counterpart (the Securities and Exchange Commission (SEC)) in matters such as authorizing the setting up of fund

\footnotetext{
${ }^{14}$ Unlike their counterparts in the U.S., Chinese mutual funds are not required to disclose the way they vote on company and shareholder resolutions. Thus, unit holders typically do not know whether the mutual funds vote for proposals that favor the tradable shareholders.

${ }^{15}$ For example, a unit holders' meeting can only be held if the owners of more than $50 \%$ of the outstanding units attend in person or via correspondence participation.
} 
management firms (Articles 13 and 14) and the launching of new funds (Article 40), approving the appointment and the change of senior management of fund management firms (Article 17), and revoking the license of a fund management firm when it deems that necessary (Article 21). Second, the government directly or indirectly owns almost all mutual fund management firms (they are often sponsored by state-controlled entities such as securities companies, banks, large listed companies, and more recently by insurance companies) (Hong Kong Stock Exchange (2004), Kim et al. (2003)). Third, the CSRC requires that the voting rights for the share structure reform proposals should rest with the investment decision committee of the fund management firm instead of individual fund managers. The investment decision committee consists of senior management of the fund management firm whose appointment or removal, according to the Securities Investment Fund Law of 2003, needs approval from the CSRC. The members of the committee are often former government bureaucrats and current members of the Communist Party. While the CSRC has a lot of influence on the investment decision committee, it has less leverage on the actions of the individual fund managers, and hence the CSRC decided to move the voting power to the investment committee. The individual fund managers are young investment professionals without any ideological ties, or strong career and monetary obligations, to the government.

Given that the voting decision is centralized at the fund house level, senior executives of fund houses need to weigh the costs and benefits of fighting hard for better compensation terms in the reform. The major benefit, as mentioned earlier, is the potential increase in the management fee that is a percentage of any increase in the size of the fund. The cost will be the loss of valuable opportunities (e.g., in terms of launching new funds, issuing new fund units) and the adverse effects on the career prospects of senior executives in the fund industry if their hard-line voting affects the fund management company's relations with the CSRC and the government. The perceived costs of upsetting the state and the CSRC may be too high for the investment decision committees and so they vote in favor of the reform proposal without bargaining for improved terms (particularly in state-owned firms, see the discussion below). Finally, the highly concentrated nature of the mutual fund industry also makes it easier for the CSRC to wield its influence on the voting of mutual fund shareholders. ${ }^{16}$ Given the above reasoning, we hypothesize:

$H 2$. Other things being equal, the level of mutual fund ownership is nonpositively related to the compensation ratio offered to the tradable shareholders.

Although this political pressure on mutual funds is applied to all share structure reform proposals, the influence is likely to be strongest for the proposals submitted by state-controlled listed firms, as the state has stronger incentives to get the reform done quickly for these firms (e.g., state-controlled firms serve as an example to other listed companies). In addition, it is easier for the government to coordinate an agreement for state-controlled listed firms, since it can

\footnotetext{
${ }^{16}$ It is easier for the government to exert influence on a small group of funds than on a large group of funds.
} 
exert influence on both the mutual fund voting and the compensation proposals of the nontradable shareholders. We therefore expect mutual funds to have a more significant negative impact on the compensation ratio in state-controlled firms. Our third hypothesis is

$H 3$. Other things being equal, the negative relation between the fund ownership and the compensation ratio strengthens with the increase of state ownership.

\section{Sample and Variables}

\section{A. Sample Selection}

Our sample initially comprises all 1,302 listed companies that have finalized their compensation plans as of the end of January 2007. However, we only focus on firms that have offered shares as the sole consideration to compensate tradable A-shareholders to ensure the comparability of compensation across firms and avoid the potential confounding effects that arise from the conversion and aggregation of different forms of compensation (e.g., warrants, cash). As a result, we exclude 248 firms from the sample. In addition, we exclude 6 financial firms. The above criteria yield a sample of 1,048 firms.

\section{B. Variables}

Data on the split share structure reform are from the Wind Financial Information System, which was commissioned by the CSRC to compile a database for regulatory use. Accounting and stock price information, as well as mutual fund and other institutional ownership, are also from Wind. Other ownership information and board structure is obtained from the China Stock Market and Accounting Research (CSMAR) database. The Appendix provides brief descriptions and summary statistics of the key variables, which we discuss next.

The final compensation ratio (i.e., the one that is eventually agreed between the 2 sets of shareholders) is the dependent variable in our analysis. We define the variable as the number of shares offered by nontradable shareholders to the tradable shareholders for every 10 tradable shares they own. ${ }^{17}$ As can be seen from the Appendix, the average number of shares received by the tradable shareholders is 3.052 for every 10 shares they already own. The standard deviation is 0.738 , suggesting some variations in the compensation ratio across firms. The minimum compensation ratio is 0.5 , and the maximum is 7 shares. We also compute an industry-adjusted compensation ratio, which is the compensation ratio for a firm minus the 2-digit industry mean compensation ratio. ${ }^{18}$

\footnotetext{
${ }^{17}$ The details on the calculation of the compensation ratio and the source of the "bonus" shares given to the tradable shareholders can be found in Appendix 1 in the early version of this paper (Firth et al. (2008)).

${ }^{18}$ In calculating the 2-digit industry mean compensation ratio, we use the firms that finalized the compensation ratio earlier in the same year and same industry to account for any time-related learning or mimicking effect in setting the compensation ratio. A more detailed industry breakdown results in a very small number of firms in some industry categories.
} 
The key independent variables of interest are state ownership and fund ownership, which we define as the number of a firm's nontradable shares owned by state-controlled entities and tradable shares owned by mutual funds, divided by the total number of shares outstanding before the reform, respectively. ${ }^{19,20} \mathrm{We}$ measure state ownership at the prior year end before the reform and fund ownership at the end of the last quarter before the reform. ${ }^{21}$ As can be seen from the Appendix, state ownership on average accounts for $32 \%$ of total shares outstanding. Mutual funds are the largest institutional investors in tradable shares. The average aggregate fund holding is $5.4 \%$ of the total shares in issue (i.e., tradable plus nontradable shares). This is about $76 \%$ of all the institutional tradable shareholdings (i.e., total tradable shareholdings by all institutions is $7.1 \%$ ) and $14 \%$ of the total tradable shares.

We also control for the percentage of the nontradable shares in our models. The greater the percentage of nontradable shares, the greater the supply of tradable shares will be after conversion, and this will lead to downward pressure on the stock price; therefore, the existing tradable shareholders need more compensation.

We use the net assets-to-price ratio (i.e., the book-to-price ratio) as a proxy for the potential gain realized by the nontradable shareholders after the reform. The rationale is that prior to the reform, nontradable shares can be transferred through private negotiations at a price that is based on the net assets per share of the firm. After the reform and after the end of the lockup period(s), the shares can be sold at market price rather than at the net asset value. Thus, the nontradable shareholders gain more from the reform if the net assets-to-price ratio is low. This reasoning suggests a negative relation between compensation and the net assets-to-price ratio. However, the ratio is also a proxy for the valuation of a firm. A low net assets-to-price ratio (i.e., a high price-to-book ratio) implies the market is positive about the prospects of the company. If so, the firm may be able to pay a lower compensation as the ratio implies the firm is well managed. Therefore, the relation between the net assets-to-price ratio and the compensation ratio is an empirical issue. The mean of the ratio is 0.512 , suggesting that on average the price of a tradable A-share is about twice the price of the nontradable share (based on net asset value).

We include several other firm-level controls. We measure firm size by the natural logarithm of book value of total assets. Capital reserve ratio, the ratio of capital reserves to total assets, is a control for the firm's capacity to offer compensation shares. The prevailing practice is that a firm first makes an issue of new

\footnotetext{
${ }^{19}$ We also compute the state ownership as the number of a firm's nontradable shares owned by state-controlled entities divided by the total number of nontradable shares (as opposed to all shares). The results from using this specification do not change the conclusions of the paper, and so we do not report them separately.

${ }^{20} \mathrm{We}$ also investigate the ownership of the nontradable shares by determining the identity of the controlling (or major) shareholder - a state entity or a private person/entity. If it is a state entity, then we code state 1 and 0 otherwise (i.e., where a private person/entity is the controlling shareholder). The results from using this alternative specification are broadly consistent with those reported in this paper, and so we do not tabulate them.

${ }^{21}$ Compared with fund ownership and other institutional ownership, state ownership typically does not fluctuate from quarter to quarter, and only annual information is available.
} 
shares using its capital reserve and then the nontradable shareholders give up their entitled shares. Higher capital reserves facilitate the payment of higher compensation. Leverage is a dummy variable, which equals 1 if the firm's debt ratio is higher than the sample mean, and 0 otherwise. A continuous leverage measure is not used due to its high correlation with the capital reserve ratio.

We include both market-based (market-adjusted stock return) and accountingbased (return on assets (ROA)) performance variables to control for the effect of performance. ROA is the past 4-year average of the net profit-to-total-assets ratio before the reform. Market-adjusted stock return is the annualized marketadjusted stock return over the 12 months before the reform. Both measures are winsorized at the $1 \%$ and $99 \%$ percentile to eliminate extreme values. Firm risk is another factor that may affect the compensation ratio. In addition to leverage, we also control for a firm's stock market risk, measured as the natural logarithm of annualized stock price volatility (standard deviation of the weekly stock return) over the 12-month period preceding the reform.

We also include several corporate governance variables to capture the effect of governance quality on the compensation ratio; that is, board size (measured by the number of directors), board independence (measured by the percentage of independent directors on the board), and managerial ownership. As discussed earlier, management shares are tradable, although there are lockup periods during which they cannot be traded.

The aforementioned governance variables focus on the internal governance schemes. We also include two external governance variables. The first one is a dummy variable, which equals 1 if the firm's financial statements are audited by one of the Big 4 international auditing firms or their joint ventures with local CPA firms, and 0 otherwise. The second variable relates to the regulatory disciplinary actions, which equals 1 if the firm has been subject to a regulatory enforcement action, and 0 otherwise. As can be seen from the Appendix, about $15.5 \%$ of the firms have been sanctioned by the CSRC.

In Table 2 we show a four-way analysis of the mean duration of the reform (measured as the number of days from the start to the completion of the reform). When state ownership is high (above the median) and mutual fund ownership is also high (above the median), the average duration is just 57 days. In contrast, when state ownership is low and mutual fund ownership is also low, the mean time for negotiations is 77 days (i.e., it takes $35 \%$ longer to complete the negotiations). The difference is significant at the 0.01 level (two-tailed). It should be noted that this comparison may overestimate the time taken for state-controlled firms to complete the reform. This is because state-controlled firms need to obtain the approval of the compensation plan from the state-owned assets administration authorities and make public such approval before the voting, whereas private firms are not subject to this requirement. The results also show that for firms with similar state ownership, higher mutual fund ownership is associated with shorter duration, and for firms with similar mutual fund ownership, higher state ownership is associated with shorter duration of the reform. The results are quite explicit: High state ownership and high mutual fund ownership are associated with faster resolutions of the compensation terms. The results in Table 2 are consistent with our predictions, which are based on the motivations of government bureaucrats 
TABLE 2

A Comparison of the Duration of the Reform

\begin{tabular}{|c|c|c|c|}
\hline State Ownership & $\begin{array}{c}\text { Mutual Fund Ownership } \leq \\
\text { Sample Median }\end{array}$ & $\begin{array}{c}\text { Mutual Fund Ownership > } \\
\text { Sample Median }\end{array}$ & $t$-Value $[p$-value $]$ \\
\hline $\begin{array}{l}\text { State Ownership < } \\
\text { Sample Median }\end{array}$ & 77.0 days & 65.1 days & $\begin{array}{c}\text { Row test: } \\
11.88^{*}[0.017]\end{array}$ \\
\hline $\begin{array}{l}\text { State Ownership > } \\
\text { Sample Median }\end{array}$ & 64.8 days & 57.2 days & $\begin{array}{c}\text { Row test: } \\
7.656^{\star}[0.031]\end{array}$ \\
\hline $\begin{array}{l}\text { Diagonal test: } \\
0.26[0.481]\end{array}$ & $\begin{array}{l}\text { Column test: } \\
12.15^{\star}[0.016]\end{array}$ & $\begin{array}{l}\text { Column test: } \\
7.92^{\star}[0.026]\end{array}$ & $\begin{array}{l}\text { Diagonal test: } \\
19.8^{* \star}[0.000]\end{array}$ \\
\hline
\end{tabular}

(who administer the state's nontradable shareholdings) and the investment decision committees of mutual funds (who vote the mutual funds' tradable shares).

\section{Empirical Results}

\section{A. Baseline Results}

To isolate the impact of ownership influences on the compensation ratio, we regress the compensation ratio on state and fund ownership, while controlling for other relevant factors. We present the empirical results in Table 3. We start with the results in Columns (1)-(4), which use the raw compensation ratio as the dependent variable. In Column (1) we run a parsimonious model with state and fund ownership and control for variables on firm risk, performance, and financial conditions. Heteroskedasticity-robust standard errors are reported.

The most striking result is that the level of state ownership is significantly and positively related to the level of the compensation ratio, which is consistent with our Hypothesis (H1) that the government bureaucrats who administer the state's shareholdings have strong incentives to complete the reform quickly and without controversy. In addition, these bureaucrats are less concerned about diluting control, as it is not their personal investment. Instead, the bureaucrats are more interested in getting the reform completed efficiently to gain credit and enhance their political careers. Mutual fund ownership is found to be negatively associated with the compensation ratio, implying that mutual funds do not fight hard for better compensation terms because of the political pressure exerted on them.

Among the control variables, the coefficient on Other Institutional Tradable Ownership is negative and statistically significant at the $1 \%$ level. The evidence suggests that pressure-sensitive institutional shareholders (e.g., insurance companies, securities companies, and investment trust companies- the Other Institutional Tradable Ownership in our case) may want to protect existing or potential business relationships with firms and are less willing to challenge management decisions (see Brickley, Lease, and Smith (1988), Cornett, Marcus, Saunders, and 
TABLE 3

Regression Results of Compensation Ratios on State and Fund Ownership

\begin{tabular}{|c|c|c|c|c|c|c|c|c|}
\hline Independent Variable & $\begin{array}{l}\text { COMP } \\
(1)\end{array}$ & $\begin{array}{l}\text { COMP } \\
(2)\end{array}$ & $\begin{array}{l}\mathrm{COMP} \\
(3)\end{array}$ & $\begin{array}{c}\text { COMP } \\
(4)\end{array}$ & $\begin{array}{l}\text { Adj. } \\
\text { COMP } \\
(5)\end{array}$ & $\begin{array}{l}\text { Adj. } \\
\text { COMP } \\
(6)\end{array}$ & $\begin{array}{l}\text { Adj. } \\
\text { COMP } \\
(7)\end{array}$ & $\begin{array}{c}\text { Adj. } \\
\text { COMP } \\
(8) \\
\end{array}$ \\
\hline State ownership & $\begin{array}{l}0.480 \\
{[0.000]^{* *}}\end{array}$ & $\begin{array}{l}0.498 \\
{[0.000]^{\star *}}\end{array}$ & $\begin{array}{l}0.591 \\
{[0.000]^{\star \star}}\end{array}$ & $\begin{array}{l}0.603 \\
{[0.000]^{\star \star}}\end{array}$ & $\begin{array}{l}0.392 \\
{[0.000]^{\star *}}\end{array}$ & $\begin{array}{l}0.405 \\
{[0.000]^{\star *}}\end{array}$ & $\begin{array}{l}0.495 \\
{[0.000]^{\star *}}\end{array}$ & $\begin{array}{c}0.498 \\
{[0.000]^{\star *}}\end{array}$ \\
\hline Fund ownership & $\begin{array}{l}-0.863 \\
{[0.000]^{\star \star}}\end{array}$ & $\begin{array}{l}-0.862 \\
{[0.000]^{\star \star}}\end{array}$ & $\begin{array}{l}-0.391 \\
{[0.170]}\end{array}$ & $\begin{array}{c}-0.398 \\
{[0.167]}\end{array}$ & $\begin{array}{l}-0.656 \\
{[0.001]^{\star \star}}\end{array}$ & $\begin{array}{l}-0.672 \\
{[0.001]^{\star \star}}\end{array}$ & $\begin{array}{l}-0.221 \\
{[0.414]}\end{array}$ & $\begin{array}{l}-0.261 \\
{[0.343]}\end{array}$ \\
\hline $\begin{array}{c}\text { Fund ownership } \times \\
\text { state ownership }\end{array}$ & & & $\begin{array}{l}-1.802 \\
{[0.004]^{\star \star}}\end{array}$ & $\begin{array}{l}-1.749 \\
{[0.006]^{\star \star}}\end{array}$ & & & $\begin{array}{l}-1.665 \\
{[0.006]^{\star *}}\end{array}$ & $\begin{array}{l}-1.552 \\
{[0.011]^{\star}}\end{array}$ \\
\hline $\begin{array}{l}\text { Other institutional } \\
\text { tradable ownership }\end{array}$ & $\begin{array}{l}-1.126 \\
{[0.009]^{* *}}\end{array}$ & $\begin{array}{l}-1.171 \\
{[0.007]^{\star *}}\end{array}$ & $\begin{array}{l}-1.145 \\
{[0.008]^{\star *}}\end{array}$ & $\begin{array}{l}-1.191 \\
{[0.007]^{\star \star}}\end{array}$ & $\begin{array}{l}-1.249 \\
{[0.005]^{\star \star}}\end{array}$ & $\begin{array}{l}-1.306 \\
{[0.004]^{\star \star}}\end{array}$ & $\begin{array}{l}-1.267 \\
{[0.005]^{\star \star}}\end{array}$ & $\begin{array}{l}-1.324 \\
{[0.004]^{\star \star}}\end{array}$ \\
\hline $\begin{array}{l}\text { Nontradable shares } \\
\text { ratio }\end{array}$ & $\begin{array}{l}2.699 \\
{[0.000]^{\star \star}}\end{array}$ & $\begin{array}{l}2.690 \\
{[0.000]^{\star \star}}\end{array}$ & $\begin{array}{l}2.678 \\
{[0.000]^{\star \star}}\end{array}$ & $\begin{array}{l}2.674 \\
{[0.000]^{\star \star}}\end{array}$ & $\begin{array}{l}2.541 \\
{[0.000]^{\star *}}\end{array}$ & $\begin{array}{l}2.536 \\
{[0.000]^{\star \star}}\end{array}$ & $\begin{array}{l}2.523 \\
{[0.000]^{* \star}}\end{array}$ & $\begin{array}{l}2.522 \\
{[0.000]^{* *}}\end{array}$ \\
\hline $\begin{array}{l}\text { Net assets-to-price } \\
\text { ratio }\end{array}$ & $\begin{array}{c}0.178 \\
{[0.056]}\end{array}$ & $\begin{array}{c}0.177 \\
{[0.060]}\end{array}$ & $\begin{array}{c}0.169 \\
{[0.068]}\end{array}$ & $\begin{array}{l}0.170 \\
{[0.071]}\end{array}$ & $\begin{array}{c}0.137 \\
{[0.105]}\end{array}$ & $\begin{array}{c}0.131 \\
{[0.123]}\end{array}$ & $\begin{array}{c}0.129 \\
{[0.127]}\end{array}$ & $\begin{array}{c}0.124 \\
{[0.143]}\end{array}$ \\
\hline Firm size & $\begin{array}{c}0.050 \\
{[0.073]}\end{array}$ & $\begin{array}{c}0.037 \\
{[0.200]}\end{array}$ & $\begin{array}{c}0.053 \\
{[0.056]}\end{array}$ & $\begin{array}{c}0.040 \\
{[0.165]}\end{array}$ & $\begin{array}{c}0.046 \\
{[0.095]}\end{array}$ & $\begin{array}{c}0.036 \\
{[0.214]}\end{array}$ & $\begin{array}{c}0.049 \\
{[0.075]}\end{array}$ & $\begin{array}{c}0.038 \\
{[0.181]}\end{array}$ \\
\hline Capital reserve & $\begin{array}{l}0.162 \\
{[0.009]^{\star \star}}\end{array}$ & $\begin{array}{l}0.156 \\
{[0.011]^{\star}}\end{array}$ & $\begin{array}{l}0.156 \\
{[0.010]^{\star \star}}\end{array}$ & $\begin{array}{c}0.150 \\
{[0.013]^{\star}}\end{array}$ & $\begin{array}{l}0.105 \\
{[0.045]^{\star}}\end{array}$ & $\begin{array}{c}0.103 \\
{[0.043]^{\star}}\end{array}$ & $\begin{array}{c}0.100 \\
{[0.052]}\end{array}$ & $\begin{array}{c}0.098 \\
{[0.053]}\end{array}$ \\
\hline Leverage dummy & $\begin{array}{l}-0.027 \\
{[0.540]}\end{array}$ & $\begin{array}{l}-0.024 \\
{[0.593]}\end{array}$ & $\begin{array}{l}-0.026 \\
{[0.559]}\end{array}$ & $\begin{array}{l}-0.022 \\
{[0.618]}\end{array}$ & $\begin{array}{l}-0.040 \\
{[0.359]}\end{array}$ & $\begin{array}{l}-0.037 \\
{[0.394]}\end{array}$ & $\begin{array}{l}-0.038 \\
{[0.373]}\end{array}$ & $\begin{array}{l}-0.035 \\
{[0.412]}\end{array}$ \\
\hline Return on assets & $\begin{array}{l}-1.592 \\
{[0.003]^{\star \star}}\end{array}$ & $\begin{array}{l}-1.588 \\
{[0.004]^{\star \star}}\end{array}$ & $\begin{array}{l}-1.591 \\
{[0.003]^{\star \star}}\end{array}$ & $\begin{array}{l}-1.578 \\
{[0.004]^{\star \star}}\end{array}$ & $\begin{array}{l}-1.654 \\
{[0.001]^{\star \star}}\end{array}$ & $\begin{array}{l}-1.679 \\
{[0.001]^{\star \star}}\end{array}$ & $\begin{array}{l}-1.653 \\
{[0.001]^{\star \star}}\end{array}$ & $\begin{array}{l}-1.671 \\
{[0.001]^{\text {** }}}\end{array}$ \\
\hline $\begin{array}{l}\text { Market-adjusted } \\
\text { stock return }\end{array}$ & $\begin{array}{c}0.001 \\
{[0.055]}\end{array}$ & $\begin{array}{c}0.001 \\
{[0.091]}\end{array}$ & $\begin{array}{c}0.001 \\
{[0.055]}\end{array}$ & $\begin{array}{c}0.001 \\
{[0.091]}\end{array}$ & $\begin{array}{c}0.001 \\
{[0.112]}\end{array}$ & $\begin{array}{c}0.001 \\
{[0.166]}\end{array}$ & $\begin{array}{c}0.001 \\
{[0.113]}\end{array}$ & $\begin{array}{c}0.001 \\
{[0.166]}\end{array}$ \\
\hline Stock volatility & $\begin{array}{c}0.144 \\
{[0.128]}\end{array}$ & $\begin{array}{c}0.135 \\
{[0.179]}\end{array}$ & $\begin{array}{c}0.145 \\
{[0.122]}\end{array}$ & $\begin{array}{c}0.139 \\
{[0.163]}\end{array}$ & $\begin{array}{c}0.054 \\
{[0.548]}\end{array}$ & $\begin{array}{c}0.041 \\
{[0.669]}\end{array}$ & $\begin{array}{c}0.056 \\
{[0.534]}\end{array}$ & $\begin{array}{c}0.045 \\
{[0.636]}\end{array}$ \\
\hline $\begin{array}{l}\text { Managerial } \\
\text { ownership }\end{array}$ & & $\begin{array}{c}6.803 \\
{[0.852]}\end{array}$ & & $\begin{array}{c}6.195 \\
{[0.867]}\end{array}$ & & $\begin{array}{c}7.918 \\
{[0.849]}\end{array}$ & & $\begin{array}{c}7.378 \\
{[0.860]}\end{array}$ \\
\hline Board independence & & $\begin{array}{c}0.655 \\
{[0.156]}\end{array}$ & & $\begin{array}{c}0.636 \\
{[0.165]}\end{array}$ & & $\begin{array}{c}0.340 \\
{[0.462]}\end{array}$ & & $\begin{array}{c}0.323 \\
{[0.481]}\end{array}$ \\
\hline Board size & & $\begin{array}{c}0.015 \\
{[0.130]}\end{array}$ & & $\begin{array}{c}0.014 \\
{[0.141]}\end{array}$ & & $\begin{array}{c}0.016 \\
{[0.096]}\end{array}$ & & $\begin{array}{c}0.015 \\
{[0.103]}\end{array}$ \\
\hline Big 4 auditor & & $\begin{array}{c}0.018 \\
{[0.773]}\end{array}$ & & $\begin{array}{c}0.012 \\
{[0.847]}\end{array}$ & & $\begin{array}{c}0.029 \\
{[0.645]}\end{array}$ & & $\begin{array}{c}0.024 \\
{[0.707]}\end{array}$ \\
\hline $\begin{array}{l}\text { Law violation } \\
\text { dummy }\end{array}$ & & $\begin{array}{l}-0.042 \\
{[0.527]}\end{array}$ & & $\begin{array}{l}-0.037 \\
{[0.569]}\end{array}$ & & $\begin{array}{l}-0.053 \\
{[0.420]}\end{array}$ & & $\begin{array}{l}-0.049 \\
{[0.452]}\end{array}$ \\
\hline $\begin{array}{l}\text { Year and industry dummy } \\
N \\
\text { Adj. } R^{2}\end{array}$ & $\begin{array}{l}\text { Yes } \\
1,042 \\
0.309\end{array}$ & $\begin{array}{l}\text { Yes } \\
1,031 \\
0.313\end{array}$ & $\begin{array}{l}\text { Yes } \\
1,042 \\
0.313\end{array}$ & $\begin{array}{l}\text { Yes } \\
1,031 \\
0.316\end{array}$ & $\begin{array}{l}\text { Yes } \\
1,042 \\
0.233\end{array}$ & $\begin{array}{l}\text { Yes } \\
1,031 \\
0.238\end{array}$ & $\begin{array}{l}\text { Yes } \\
1,042 \\
0.236\end{array}$ & $\begin{array}{l}\text { Yes } \\
1,031 \\
0.241\end{array}$ \\
\hline
\end{tabular}

Tehranian (2007), and Mehran and Stulz (2007) for evidence from the U.S. on institutional investors protecting their business interests). These conflicts of interest may lead institutional shareholders to accept lower compensation in order to curry favor with the firm's management team. In addition, other institutional investors that are owned by the state may also be under pressure from the CSRC to agree to the compensation terms.

As expected, compensation is higher in firms that have a greater proportion of nontradable shares. In such firms, the greater supply of tradable shares after the reform may exert a higher downward pressure on stock price and so higher compensation is required. The coefficient on Capital Reserve is positive and highly significant, suggesting that higher capital reserves facilitate the payment of higher 
compensation. As for the performance variables, the coefficient on Return on Assets is negative and significant at the 0.01 level. Therefore, firms with good historical performance pay lower compensation than do firms with poor historical performance. The other performance measure, Market-Adjusted Stock Return, is found to have a positive but insignificant impact on compensation ratio at the $5 \%$ level or better. No other control variables are found to have a significant impact on the compensation ratio. In Column (2), we add governance control variables into the regression, and they are found to have little effect on the compensation ratio. Managerial Ownership has a positive coefficient, but it is not statistically significant. Managers own tradable shares, and so they benefit from higher compensation. However, they have limited influence on the compensation ratio, as they are not directly involved in the negotiations. This helps explain the positive but insignificant coefficient.

In Columns (3) and (4) of Table 3 we include a multiplicative interaction term between fund ownership and state ownership to test for the possibility that the effect of fund ownership on the compensation ratio is conditioned on the level of state ownership. The results show that the coefficients on the interaction term are negative and significant at the 0.01 level. Therefore, the negative effect of fund ownership on the compensation ratio is strengthened with the increase of state ownership. In other words, the positive link between state ownership and the compensation ratio is substantially weakened by mutual fund ownership, other things being equal. Also, note that in firms without any state ownership, the coefficients on fund ownership are negative but insignificant. These results provide support for our hypothesis that political pressure on mutual funds is likely to be higher in firms with a substantial level of state ownership than in firms controlled by private owners. In fact, the "helping hand" effects of mutual funds are directed mainly toward state-controlled firms, and the effects toward private firms are not statistically significant. The marginal effect of state ownership on the compensation ratio is $(0.603-1.749 \times$ Fund Ownership) (based on the results in Column (4)). Thus, firms with state ownership pay lower compensation if there is a high level of mutual fund ownership of the tradable shares. Here, the major nontradable shareholders believe that mutual funds will be acquiescent in accepting the terms offered (due to pressure from the CSRC), and they take advantage of this by proposing lower compensation. However, when mutual fund ownership is absent or very low, the nontradable shareholders need to negotiate with individual shareholders, and these investors are more politically pressure-resistant and less compliant than mutual funds. Our evidence illustrates quite clearly that, in the particular circumstance of the share structure reform, the state influences both parties of the compensation negotiation process. On the one hand, the state allows firms with state ownership to offer higher compensation to ensure the smoothness of the reform negotiations. On the other hand, the state also exerts influence (via the CSRC) on mutual fund shareholders, the largest group of tradable shareholders (and maybe other institutional shareholders as well), to ensure that they "cooperate" with the government's desire for a noncontentious proposal, and this, in effect, reduces the compensation ratio offered by state-owned firms. Our results also show that the mutual funds do not act in the best interests of their unit holders. Instead, they appear to be agents of the state, carrying out the wishes 
of the CSRC. In private firms, the Fund Ownership coefficients are negative, although not significant, and so even here, mutual funds do not bargain for better compensation.

In Columns (5)-(8) of Table 3 we use the industry-mean-adjusted compensation ratio as the dependent variable. The industry-adjusted ratio provides a more explicit control for the possible industry patterns in offering compensation. Clearly, the results in Columns (5)-(8) are qualitatively similar to those of Columns (1)-(4), respectively, and so we do not comment on them any further.

\section{B. Results from the Market Event Analysis}

In order to gain more insights into the reform, we conduct a market event analysis and explore the market reaction to the announcement of the final compensation ratio. We obtain prices that appropriately adjust for capitalization changes and distributions in calculating stock and index returns from Wind. We then use the single-factor market model to estimate beta and normal returns. The market index is the Shanghai Composite Index for companies listed on the Shanghai Stock Exchange and the Shenzhen Composite Index for companies listed on the Shenzhen Stock Exchange. These market indexes include all the common stocks listed on the respective stock exchanges, and they are commonly used in event studies in China. The market model has been used extensively in China (see Chen, Firth, Gao, and Rui (2005)). We use Day 0 to denote the announcement day and Day 1 to denote the first trading day following the announcement of the compensation plan (note that the proposed compensation needs to be voted on at the shareholders' meeting later). The results reported in Table 4 are based on an estimation window of $[-4,-63] .{ }^{22}$ The mean 2-day cumulative abnormal return (CAR) following the announcement of the final compensation ratio is $3.6 \%$ (Panel B, Window $[1,2]$ ), indicating that stock prices typically experience a significant rise following the announcement. This implies that the final terms of the compensation are better than expected and/or there is a palpable relief that the firm can now move forward and management can concentrate on improving operating performance. ${ }^{23}$

The abnormal return on Day 1 is regressed on state ownership and mutual fund ownership, while controlling for the compensation ratio and other factors. To investigate whether the market reaction varies between firms with and without fund ownership, we include an interaction term between a dummy mutual fund ownership variable (one for firms with fund ownership) and the compensation ratio $(\mathrm{COMP} \times \mathrm{DFUND})$. The results, presented in Table 5, show: i) there is no statistically significant relation between state and fund ownership per se on the abnormal return on Day 1, while there is a positive and significant relation between the announced compensation ratio and abnormal return; and ii) the

\footnotetext{
${ }^{22} \mathrm{We}$ also use several alternative estimation windows, but they yield similar results to those reported in Table 4.

${ }^{23}$ We note that the positive and significant stock return is also consistent with an alternative argument that successfully negotiated compensation ratios will imply a higher liquidity and a lower cost in the trading of the firm's stocks, which may help lower a firm's cost of capital (Amihud and Mendelson (2000)). We thank Stephen Brown (the editor) for pointing this out.
} 
Table 4 presents the results of an event study on the market reaction to the announcement of the final compensation ratio. Prices that appropriately adjust for capitalization changes and distributions are used in calculating stock and index returns. A single-factor market model is used to estimate beta and normal returns. The chosen market index is the Shanghai Composite Index for companies listed on the Shanghai Stock Exchange and the Shenzhen Composite Index for companies listed on the Shenzhen Stock Exchange. These market indexes include all the common stocks listed on the respective stock exchange, and they are commonly used in event studies in China. We use Day 0 to denote the announcement day and Day 1 to denote the first trading day following the announcement of the compensation plan. Abnormal return $=$ actual stock return - stock return predicted by the single-factor market model based on the estimation period of [-4, -63$]$. $t$-values are reported in brackets. ${ }^{\star \star}$ denotes significance at the $1 \%$ level.

Panel A. Abnormal Return (AR)

\begin{tabular}{|c|c|c|c|c|c|c|}
\hline Day & -3 & -2 & -1 & 1 & 2 & 3 \\
\hline Mean AR & $\begin{array}{l}0.004 \\
{[5.155]^{\star \star}}\end{array}$ & $\begin{array}{l}0.005 \\
{[6.232]^{\star \star}}\end{array}$ & $\begin{array}{c}0.007 \\
{[8.891]^{\star \star}}\end{array}$ & $\begin{array}{c}0.026 \\
{[13.755]^{\star \star}}\end{array}$ & $\begin{array}{l}0.010 \\
{[7.766]^{\star \star}}\end{array}$ & $\begin{array}{l}0.008 \\
{[7.245]^{\star \star}}\end{array}$ \\
\hline \multicolumn{7}{|c|}{ Panel B. Cumulative Abnormal Return (CAR) } \\
\hline Days & & {$[-1,1]$} & & {$[-1,2]$} & & {$[1,2]$} \\
\hline Mean CAR & & $\begin{array}{c}0.033 \\
{[16.338]^{\star \star}}\end{array}$ & & $\begin{array}{c}0.043 \\
{[15.657]^{\star \star}}\end{array}$ & & $\begin{array}{c}0.036 \\
{[13.584]^{\star \star}}\end{array}$ \\
\hline
\end{tabular}

coefficient on the interaction term is negative and statistically significant in the pooled analysis (Column (1)). This indicates that the presence of fund ownership weakens the positive link between announced compensation ratio and abnormal return. Thus, the abnormal stock return for firms with fund ownership is significantly lower than that for firms without fund ownership. Individual investors in tradable A-shares seem to be disappointed at the role of mutual funds in the reform bargaining process. A further analysis (reported in Column (2) "State Ownership $\leq$ Median" and Column (3) "State Ownership > Median") indicates that the lower market return experienced by firms that have mutual funds as investors is much more pronounced in firms with higher-than-sample-median state ownership than in other firms. These results provide additional support for our argument that mutual funds are reluctant to fight for better compensation, and this especially applies in firms with a high level of state ownership.

In Columns (4)-(6) of Table 5 we add the interaction term between the dummy variable of other institutional tradable ownership (DOTHER) and the compensation ratio to the regression model. The coefficients on the interaction term COMP $\times$ DFUND are still negative and significant in the pooled sample and in the sample of firms with higher-than-sample-median state ownership. The coefficients on COMP $\times$ DOTHER are always negative but only significant in firms with higher-than-sample-median state ownership. This suggests that individual investors are also disappointed at the role of pressure-sensitive institutional investors other than mutual funds in the reform negotiation process of firms with higher-than-sample-median state ownership.

\section{Why Do Individual Investors Feel Disappointed?}

We next explore why individual investors feel ex post disappointed with the voting actions of the mutual funds. It is plausible that for firms with mutual fund ownership, individual investors will choose to free ride and rely on the mutual funds in the bargaining process. This is because they may believe mutual funds 


\section{TABLE 5}

Regression Results of Abnormal Returns on Day 1 on Fund Ownership

Table 5 presents the regression results of abnormal returns on Day 1 on fund ownership, controlling for compensation ratio (COMP) and other variables. Day 0 is the announcement day, and Day 1 is the first trading day following the announcement. DFUND $=1$ if a firm has fund ownership and 0 otherwise. DOTHER $=1$ if a firm has other institutional tradable ownership and 0 otherwise. Abnormal return = actual stock return - stock return predicted by the market model based on the estimation period of $[-4,-63]$. Robust $p$-values are reported in brackets. ${ }^{\star \star}$ and ${ }^{\star}$ denote significance at the $1 \%$ and $5 \%$ levels, respectively.

\begin{tabular}{|c|c|c|c|c|c|c|}
\hline & Pooled & $\begin{array}{c}\text { State } \\
\text { Ownership } \leq \\
\text { Median }\end{array}$ & $\begin{array}{c}\text { State } \\
\text { Ownership }> \\
\text { Median }\end{array}$ & Pooled & $\begin{array}{c}\text { State } \\
\text { Ownership } \\
\text { Median }\end{array}$ & $\begin{array}{c}\text { State } \\
\text { Ownership > } \\
\text { Median }\end{array}$ \\
\hline Independent Variable & (1) & (2) & (3) & (4) & (5) & (6) \\
\hline State ownership & $\begin{array}{l}-0.003 \\
{[0.738]}\end{array}$ & $\begin{array}{c}0.014 \\
{[0.676]}\end{array}$ & $\begin{array}{l}-0.007 \\
{[0.796]}\end{array}$ & $\begin{array}{l}-0.003 \\
{[0.780]}\end{array}$ & $\begin{array}{c}0.015 \\
{[0.655]}\end{array}$ & $\begin{array}{l}-0.009 \\
{[0.733]}\end{array}$ \\
\hline Fund ownership & $\begin{array}{c}0.008 \\
{[0.694]}\end{array}$ & $\begin{array}{c}0.014 \\
{[0.627]}\end{array}$ & $\begin{array}{l}-0.015 \\
{[0.581]}\end{array}$ & $\begin{array}{c}0.012 \\
{[0.557]}\end{array}$ & $\begin{array}{c}0.016 \\
{[0.608]}\end{array}$ & $\begin{array}{l}-0.009 \\
{[0.735]}\end{array}$ \\
\hline COMP $\times$ DFUND & $\begin{array}{l}-0.004 \\
{[0.003]^{\star \star}}\end{array}$ & $\begin{array}{l}-0.003 \\
{[0.103]}\end{array}$ & $\begin{array}{l}-0.005 \\
{[0.009]^{\star *}}\end{array}$ & $\begin{array}{l}-0.003 \\
{[0.008]^{\star *}}\end{array}$ & $\begin{array}{l}-0.003 \\
{[0.107]}\end{array}$ & $\begin{array}{l}-0.004 \\
{[0.034]^{*}}\end{array}$ \\
\hline $\begin{array}{l}\text { Other institutional tradable } \\
\text { ownership }\end{array}$ & $\begin{array}{c}0.028 \\
{[0.582]}\end{array}$ & $\begin{array}{c}0.130 \\
{[0.113]}\end{array}$ & $\begin{array}{l}-0.075 \\
{[0.354]}\end{array}$ & $\begin{array}{c}0.077 \\
{[0.174]}\end{array}$ & $\begin{array}{c}0.141 \\
{[0.126]}\end{array}$ & $\begin{array}{c}0.010 \\
{[0.911]}\end{array}$ \\
\hline COMP $\times$ DOTHER & & & & $\begin{array}{l}-0.003 \\
{[0.097]}\end{array}$ & $\begin{array}{l}-0.001 \\
{[0.781]}\end{array}$ & $\begin{array}{l}-0.004 \\
{[0.046]^{*}}\end{array}$ \\
\hline Firm size & $\begin{array}{c}0.000 \\
{[0.956]}\end{array}$ & $\begin{array}{c}0.000 \\
{[0.932]}\end{array}$ & $\begin{array}{c}0.001 \\
{[0.725]}\end{array}$ & $\begin{array}{c}0.001 \\
{[0.748]}\end{array}$ & $\begin{array}{c}0.000 \\
{[0.904]}\end{array}$ & $\begin{array}{c}0.002 \\
{[0.451]}\end{array}$ \\
\hline Tradable shares ratio & $\begin{array}{c}0.005 \\
{[0.810]}\end{array}$ & $\begin{array}{c}0.001 \\
{[0.977]}\end{array}$ & $\begin{array}{l}-0.001 \\
{[0.970]}\end{array}$ & $\begin{array}{c}0.004 \\
{[0.850]}\end{array}$ & $\begin{array}{c}0.001 \\
{[0.983]}\end{array}$ & $\begin{array}{l}-0.007 \\
{[0.858]}\end{array}$ \\
\hline Compensation ratio & $\begin{array}{l}0.013 \\
{[0.000]^{\star \star}}\end{array}$ & $\begin{array}{l}0.016 \\
{[0.000]^{\star *}}\end{array}$ & $\begin{array}{c}0.004 \\
{[0.384]}\end{array}$ & $\begin{array}{c}0.014 \\
{[0.000]^{* *}}\end{array}$ & $\begin{array}{l}0.016 \\
{[0.000]^{\star \star}}\end{array}$ & $\begin{array}{c}0.005 \\
{[0.360]}\end{array}$ \\
\hline Leverage & $\begin{array}{c}0.000 \\
{[0.437]}\end{array}$ & $\begin{array}{l}-0.004 \\
{[0.344]}\end{array}$ & $\begin{array}{c}0.000 \\
{[0.634]}\end{array}$ & $\begin{array}{c}0.000 \\
{[0.436]}\end{array}$ & $\begin{array}{l}-0.004 \\
{[0.346]}\end{array}$ & $\begin{array}{c}0.000 \\
{[0.547]}\end{array}$ \\
\hline Intercept & $\begin{array}{l}-0.019 \\
{[0.492]}\end{array}$ & $\begin{array}{l}-0.033 \\
{[0.432]}\end{array}$ & $\begin{array}{c}0.010 \\
{[0.817]}\end{array}$ & $\begin{array}{c}-0.025 \\
{[0.361]}\end{array}$ & $\begin{array}{c}-0.034 \\
{[0.416]}\end{array}$ & $\begin{array}{c}0.001 \\
{[0.987]}\end{array}$ \\
\hline $\begin{array}{l}\text { Year and industry dummies } \\
N \\
\text { Adj. } R^{2}\end{array}$ & $\begin{array}{l}\text { yes } \\
1,042 \\
0.037\end{array}$ & $\begin{array}{r}\text { yes } \\
527 \\
0.053\end{array}$ & $\begin{array}{r}\text { yes } \\
515 \\
0.049\end{array}$ & $\begin{array}{r}\text { yes } \\
1,042 \\
0.040\end{array}$ & $\begin{array}{r}\text { yes } \\
527 \\
0.053\end{array}$ & $\begin{array}{r}\text { yes } \\
515 \\
0.056\end{array}$ \\
\hline
\end{tabular}

will fight for better compensation terms and/or they think that their diffuse ownerships cannot exert a significant influence on the bargaining process when a large block of fund ownership is present. In contrast, in firms without mutual fund ownership, individual investors are more likely to actively engage in the voting process and fight for themselves. To test this, we collect data on the proportion of individual tradable A-shares that participate in the voting and test the difference between firms with and without mutual fund ownership. Table 6 presents the results.

\section{TABLE 6}

Voting Rates by Individual Investors: Firms with versus without Fund Ownership

Table 6 compares the voting rates by individual tradable-share investors between firms with and without fund ownership. Voting rate is the proportion of tradable shares owned by individual investors that participated in the vote. ** denotes significance at the $1 \%$ level.

\begin{tabular}{llllllll}
\multicolumn{1}{c}{ Predicted Sign } & $\frac{\text { Mean }}{n n n n}$ & $\frac{\text { Std. Dev. }}{0.06}$ & $\frac{\text { Mean }}{0.251}$ & $\frac{\text { Std. Dev. }}{0.007}$ & $\frac{t \text {-Stat. }}{[9.214]^{* *}}$ & $\frac{\begin{array}{c}\text { Wilcoxon } \\
\text { With fund ownership }>\end{array}}{\text { Without fund ownership }}$
\end{tabular}


We find that the mean voting rate of individual investors in firms without fund ownership is $25.1 \%$ of the total number of tradable shares owned by individuals, which is over 4 times the voting rate of individual shareholders $(6 \%)$ in firms with mutual fund ownership. The difference is statistically significant at the 0.01 level. The individual investors vote less frequently if the listed firm has a mutual fund as an investor. Thus, the individual investors appear to rely on mutual funds to force through a good deal on compensation. However, based on the stock return analyses, investors seem disappointed with the outcomes.

\section{Conclusion}

In the past 20 years, there has been a significant increase in corporate privatization and restructuring in transitional economies, and this has received significant research attention in the literature. At the same time, the institutional ownership of common stocks has increased dramatically worldwide over the same period. In developed markets, institutional investors, such as mutual funds, are generally believed to monitor management and to fight hard to maximize stock returns, and their actions benefit the small individual investors. However, our understanding of the role that institutional shareholders (e.g., mutual funds) play in corporate governance and investor protection in emerging markets is quite limited. In this paper, we add to the two strands of literature by exploring the role of government shareholders and mutual funds in the bargaining process of the split share structure reform in China. This represents an ideal setting to examine governance issues because it is unlikely to suffer from the problems (e.g., endogeneity) that normally plague these types of studies.

In 2005-2006, the Chinese government launched a full-scale reform of listed firms to make nonpublicly tradable shares publicly tradable. To obtain the flotation rights of their shares, nontradable shareholders need to negotiate a compensation plan with the tradable shareholders and eventually obtain their approval. The state plays a unique role in the reform through its ability to influence the parties to the negotiation (particularly in state-owned firms). The mutual fund shareholders also play a crucial role in this negotiation process. We analyze the incentive structure of both the government and the mutual funds as shareholders in listed firms.

Firms whose nontradable shares are primarily owned by the state offer higher compensation than firms whose nontradable shares are primarily owned by private investors. This finding is consistent with our arguments that the state is very concerned with a speedy and noncontroversial resolution of the reform and that the state bureaucrats are not as concerned with dilution of control as are private investors. Our empirical tests also indicate that mutual fund ownership has a negative and statistically significant effect on the final compensation ratio. More importantly, we find that mutual fund ownership weakens the positive link between state ownership and compensation, suggesting that mutual funds help state-owned firms get the reform done more quickly and at a relatively lower cost. In fact, after controlling for the interaction term between state ownership and mutual fund ownership, the negative effects of mutual funds become insignificant, suggesting that the helping hand from mutual funds is geared mainly toward the state-owned 
listed companies. This result is in stark contrast to the argument that mutual funds will strive for better returns for their unit holders (and, by extension, the individual shareholders) by seeking higher compensation.

Overall, these findings shed some light on the political influence of the state and the compromised role of mutual funds in the split share structure reform in China. Although the Chinese government is gradually relinquishing its control over economic matters, our results clearly indicate that the state still intercedes to apply strong political pressure when there are specific policy initiatives it wants to enforce. A major implication of our findings is that mutual funds are not a crutch that the individual shareholders can rely on, as the "free ride" for individual shareholders results in lower compensation than would otherwise be the case. An event study that examines the market reaction to the announcement of the final compensation ratio suggests that individual investors are disappointed at the role of mutual funds in the reform bargaining process in the state-controlled firms. Our study represents an important extension to the literature on the role of mutual funds by focusing on the incentives and pressures they face in the world's fastestgrowing economy.

\begin{tabular}{|c|c|c|c|c|c|}
\hline & $\begin{array}{c}\text { APPENDIX } \\
\text { Variable Definitions }\end{array}$ & & & & \\
\hline Variable & Definition & Mean & Median & Std. Dev. & $N$ \\
\hline Compensation ratio & $\begin{array}{l}\text { Number of shares given by nontradable } \\
\text { shareholders to tradable shareholders } \\
\text { for every } 10 \text { tradable shares already } \\
\text { owned. }\end{array}$ & 3.052 & 3.100 & 0.738 & 1,048 \\
\hline $\begin{array}{l}\text { Industry-adjusted } \\
\text { compensation ratio }\end{array}$ & $\begin{array}{l}\text { Industry-mean-adjusted compensation ratio } \\
\text { based on the CSRC } 2001 \text { two-digit in- } \\
\text { dustry code. }\end{array}$ & 0.000 & 0.038 & 0.690 & 1,048 \\
\hline State ownership & $\begin{array}{l}\text { Number of shares held by the government } \\
\text { and state-owned enterprises } \div \text { total } \\
\text { number of shares in issue of the firm } \\
\text { measured at the prior year end before } \\
\text { the reform. }\end{array}$ & 0.320 & 0.000 & 0.467 & 1,048 \\
\hline Fund ownership & $\begin{array}{l}\text { Number of shares in a firm held by mutual } \\
\text { funds } \div \text { total number of shares in issue } \\
\text { of the firm measured at the end of the } \\
\text { quarter before the reform. }\end{array}$ & 0.054 & 0.001 & 0.110 & 1,048 \\
\hline $\begin{array}{l}\text { Other institutional tradable } \\
\text { ownership }\end{array}$ & $\begin{array}{l}\text { Number of tradable shares held by other in- } \\
\text { stitutional investors } \div \text { total number of } \\
\text { shares in issue measured at the end of } \\
\text { the quarter before the reform. }\end{array}$ & 0.017 & 0.000 & 0.036 & 1,048 \\
\hline Nontradable shares & $\begin{array}{l}\text { Number of nontradable shares } \div \text { the total } \\
\text { number of shares in issue measured at } \\
\text { the prior year end before the reform. }\end{array}$ & 0.610 & 0.625 & 0.109 & 1,048 \\
\hline Net assets-to-price ratio & $\begin{array}{l}\text { Net assets per share to tradable A-share } \\
\text { price ratio. Price is the } 3 \text {-month average } \\
\text { price before the reform. }\end{array}$ & 0.512 & 0.484 & 0.349 & 1,045 \\
\hline Firm size & $\begin{array}{l}\text { Company size defined as the natural log of } \\
\text { book value of total assets. }\end{array}$ & 11.981 & 11.922 & 0.969 & 1,048 \\
\hline Capital reserve ratio & Capital reserves $\div$ total assets. & 0.219 & 0.188 & 0.320 & 1,048 \\
\hline Leverage dummy & $\begin{array}{l}\text { Equals } 1 \text { if a firm's total debt ratio } \geq \text { the mean } \\
\text { of the sample's total debt ratio, and } 0 \\
\text { otherwise. }\end{array}$ & 0.252 & 0.258 & 0.219 & 1,052 \\
\hline Return on assets & $\begin{array}{l}\text { Four-year average of the net profit-to-total- } \\
\text { assets ratio before the reform. }\end{array}$ & 0.025 & 0.029 & 0.062 & 1,053 \\
\hline
\end{tabular}




\begin{tabular}{|c|c|c|c|c|c|}
\hline \multicolumn{6}{|c|}{$\begin{array}{l}\text { APPENDIX (continued) } \\
\text { Variable Definitions }\end{array}$} \\
\hline Variable & Definition & Mean & Median & Std. Dev. & $N$ \\
\hline $\begin{array}{r}\text { Market-adjusted } \\
\text { stock return }\end{array}$ & $\begin{array}{l}\text { Annualized abnormal stock return over the } 12 \\
\text { months before the reform (actual stock } \\
\text { return - the expected return from the } \\
\text { market model). }\end{array}$ & 1.685 & -1.828 & 32.619 & 1,048 \\
\hline Stock volatility & $\begin{array}{l}\text { Log of annualized standard deviation of } \\
\text { weekly stock return over the 12-month } \\
\text { period before the reform. }\end{array}$ & 3.619 & 3.618 & 0.271 & 1,048 \\
\hline Managerial ownership & $\begin{array}{l}\text { Number of shares owned by a firm's directors } \\
\text { and managers } \div \text { total number of shares } \\
\text { in issue, measured at the prior year end } \\
\text { before the reform. }\end{array}$ & 0.000 & 0.000 & 0.000 & 1,037 \\
\hline Board independence & $\begin{array}{l}\text { Number of independent directors on the } \\
\text { board } \div \text { board size. }\end{array}$ & 0.345 & 0.333 & 0.045 & 1,048 \\
\hline Board size & Number of directors on the board. & 9.674 & 9.000 & 2.078 & 1,048 \\
\hline Big 4 auditor dummy & $\begin{array}{l}\text { Equals } 1 \text { if the firm's financial statements are } \\
\text { audited by one of the Big } 4 \text { accounting } \\
\text { firms or their joint ventures in the year be- } \\
\text { fore the reform. }\end{array}$ & 0.135 & 0.000 & 0.341 & 1,048 \\
\hline Law violation dummy & $\begin{array}{l}\text { Equals } 1 \text { if the firm (or its directors and man- } \\
\text { agers) received CSRC disciplinary ac- } \\
\text { tions before the reform, and } 0 \text { otherwise. }\end{array}$ & 0.155 & 0.000 & 0.362 & 1,048 \\
\hline
\end{tabular}

\section{References}

Amihud, Y., and H. Mendelson. "The Liquidity Route to a Lower Cost of Capital." Journal of Applied Corporate Finance, 12 (2000), 8-25.

Brickley, J. A.; R. C. Lease; and C. W. Smith, Jr. "Ownership Structure and Voting on Antitakeover Amendments." Journal of Financial Economics, 20 (1988), 267-291.

Chen, G. M.; M. Firth; D. N. Gao; and O. M. Rui. "Is China's Securities Regulatory Agency a Toothless Tiger? Evidence from Enforcement Actions." Journal of Accounting and Public Policy, 24 (2005), 451-488.

Chen, G. M.; M. Firth; D. N. Gao; and O. M. Rui. "Ownership Structure, Corporate Governance, and Fraud: Evidence from China." Journal of Corporate Finance, 12 (2006), 424-448.

Chen, G. M.; M. Firth; and O. M. Rui. "Have China's Enterprise Reforms Led to Improved Efficiency and Profitability?" Emerging Markets Review, 7 (2006), 82-109.

Chen, G. M.; M. Firth; Y. Xin; and L. Xu. "Control Transfers, Privatization, and Corporate Performance: Efficiency Gains in China's Listed Companies." Journal of Financial and Quantitative Analysis, 43 (2008), 161-190.

Chen, J. J. "70 Billion Yuan State-Owned Assets Await Listing in Shanghai." Shanghai Securities Daily (in Chinese), April 24, 2008.

Chevalier, J., and G. Ellison. "Risk Taking by Mutual Funds as a Response to Incentives." Journal of Political Economy, 105 (1997), 1167-1200.

China Securities Regulatory Commission (CSRC). Experimental Rules on Open-End Mutual Funds (2000).

Chow, G. C. China's Economic Transformation. 2nd ed., New York, NY: Wiley-Blackwell (2007).

Cornett, M. M.; A. J. Marcus; A. Saunders; and H. Tehranian. "The Impact of Institutional Ownership on Corporate Operating Performance." Journal of Banking and Finance, 31 (2007), 1771-1794.

Davis, G. F., and E. H. Kim. "Business Ties and Proxy Voting by Mutual Funds." Journal of Financial Economics, 85 (2007), 552-570.

Feinerman, J. V. "New Hope for Corporate Governance in China?" China Quarterly, 191 (2007), 590-612.

Ferris, S. P., and X. Yan. "Do Independent Directors and Chairmen Matter? The Role of Boards of Directors in Mutual Fund Governance." Journal of Corporate Finance, 13 (2007), 392-420.

Firth, M.; C. Lin; and H. Zou. "Friend or Foe? The Role of State and Mutual Fund Ownership in the Split Share Structure Reform in China.” Working Paper, Lingnan University of Hong Kong (2008). 
Gaspar, J.-M.; M. Massa; and P. Matos. "Shareholder Investment Horizons and the Market for Corporate Control.” Journal of Financial Economics, 76 (2005), 135-165.

Gupta, N. "Partial Privatization and Firm Performance." Journal of Finance, 60 (2005), 987-1015.

Hartzell, J. C., and L. T. Starks. "Institutional Investors and Executive Compensation." Journal of Finance, 58 (2003), 2351-2374.

Hong Kong Stock Exchange. "Institutional Investors in Mainland China.” Research and Planning Department Report (January 2004).

Huang, J. Z. "Funds' Rent Seeking in Share Structure Reform." Economy Monthly (in Chinese), 6 (2006), 60-61.

Kahl, M.; J. Liu; and F. A. Longstaff. "Paper Millionaires: How Valuable Is Stock to a Stockholder Who Is Restricted from Selling It?” Journal of Financial Economics, 67 (2003), 385-410.

Khorana, A.; P. Tufano; and L. Wedge. "Board Structure, Mergers, and Shareholder Wealth: A Study of the Mutual Fund Industry." Journal of Financial Economics, 85 (2007), 571-598.

Kim, Y.; I. S. M. Ho; and M. St. Giles. "Developing Institutional Investors in People's Republic of China." World Bank Country Study Paper (2003).

Longstaff, F. A. "How Much Can Marketability Affect Security Values?" Journal of Finance, 50 (1995), 1767-1774.

Longstaff, F. A. "Optimal Portfolio Choice and the Valuation of Illiquid Securities." Review of Financial Studies, 14 (2001), 407-431.

Lu, Y. "The Seven Vacuums in the Mutual Fund System in China." China Securities Daily (in Chinese) (February 18, 2006).

Mahoney, P. G. "Manager-Investor Conflicts in Mutual Funds." Journal of Economic Perspectives, 18 (2004), 161-182.

Mehran, H., and R. M. Stulz. "The Economics of Conflicts of Interest in Financial Institutions." Journal of Financial Economics, 85 (2007), 267-296.

Parrino, R.; R. W. Sias; and L. T. Starks. "Voting with Their Feet: Institutional Ownership Changes around Forced CEO Turnover." Journal of Financial Economics, 68 (2003), 3-46.

Tenev, S.; C. Zhang; and L. Brefort. Corporate Governance and Enterprise Reform in China: Building the Institutions of Modern Markets. Washington, DC: World Bank and the International Finance Corporation (2002).

Wahal, S. "Pension Fund Activism and Firm Performance." Journal of Financial and Quantitative Analysis, 31 (1996), 1-23.

Yuan, R. L.; J. Z. Xiao; and H. Zou. "Mutual Funds' Ownership and Firm Performance: Evidence from China." Journal of Banking and Finance, 32 (2008), 1552-1565. 